\title{
Lithium isotopes in marine food webs
}

\author{
FANNY THIBON $^{1}$, LUCAS WEPPE ${ }^{1}$, PACO \\ BUSTAMANTE $^{2}$, FRANÇOIS OBERHÄNSLI ${ }^{3}$, MARC \\ METIAN $^{3}$, CARINE CHURLAUD ${ }^{2}$, MARYLINE \\ MONTANES $^{1}$, THOMAS LACOUE-LABARTHE ${ }^{2}$, PHILIPPE \\ TELOUK $^{4}$, YVES CHEREL ${ }^{5}$ AND NATHALIE VIGIER ${ }^{6}$ \\ ${ }^{1}$ LOV- CNRS-Sorbonne Université \\ ${ }^{2}$ LIENSs - CNRS-La Rochelle Université \\ ${ }^{3}$ IAEA-REL \\ ${ }^{4}$ ENS Lyon \\ ${ }^{5} \mathrm{CEBC}$ - CNRS-La Rochelle Université \\ ${ }^{6}$ LOV - CNRS - Sorbonne Université \\ Presenting Author: thibon.fanny@orange.fr
}

Lithium (Li) production has massively increased over the past decades and is essentially used for batteries, ceramics, and medicine [1-2]. However, $\mathrm{Li}$ concentrations and its isotopic compositions $\left(\delta^{7} \mathrm{Li}\right)$ are poorly documented in aquatic ecosystems, despite its accumulation in marine organisms, especially at the base of the trophic webs [3]. Here, we present field and laboratory studies reporting $\delta^{7} \mathrm{Li}$ in various organs and whole organisms of marine plankton, bivalves, cephalopods, crustaceans, and fish collected in different biogeographical regions (the Mediterranean Sea, Bay of Biscay (BB), New Caledonia (NC), and Kerguelen Islands). The main aim of the study was to assess the role of ecological and environmental parameters on $\delta^{7} \mathrm{Li}$ values.

$\delta^{7} \mathrm{Li}$ values ranged from $4.6 \%$ (digestive gland of bivalves) to $31.7 \%$ ( $>35 \mu \mathrm{m}$ plankton). Seawater $\delta^{7} \mathrm{Li}$ being homogeneously distributed at $\sim 31.2 \%$, marine organisms thus fractionate $\mathrm{Li}$ isotopes in favor of the light isotope $\left({ }^{6} \mathrm{Li}\right)$. There are no trends in $\delta^{7} \mathrm{Li}$ values with the trophic position. However, when the same organs from similar organisms (bivalves, cephalopods, crustaceans, and fish) are compared, lower $\delta^{7} \mathrm{Li}$ are systematically found in $\mathrm{NC}$ compared to $\mathrm{BB}$, overall suggesting an influence of the environmental conditions on $\delta^{7} \mathrm{Li}$. Moreover, cultured organisms $\mathrm{Li}$ isotope fractionation increases when facing high Li levels in water.

Within the same taxonomic group, significant differences were also observed among organs with the lowest $\delta^{7} \mathrm{Li}$ values in gills for fish and in the digestive gland for bivalves. This indicates a key role of physiology on $\mathrm{Li}$ isotopes distribution. A trend with $\mathrm{Na}$ contents supports an intimate link between Li transport and regulation and the activity of $\mathrm{Na}-\mathrm{H}$ Exchangers [4]. Overall, the work highlights the interest of $\delta^{7} \mathrm{Li}$ to investigate $\mathrm{Li}$ ecotoxicology and physiology. It may also help to unravel the magnitude of biological activity ("vital effects") on $\delta^{7} \mathrm{Li}$ measured in fossil biogenic carbonates.

[1] Choi et al. (1998), Nat. Commun. 10, 5371-5378. [2] Léguérinel et al. (2018), COMES seminar. [3] Thibon and Weppe et al. (2020), Stoten, 751, 141453. [4] Counillon et al. (2016), Biochim. Biophys. Acta. 1863, 2465-2480 